\title{
The Role of Internal Communication, Work Discipline, And Employee Loyalty on Employee Performance
}

\author{
Purnamie TITISARI $^{1 *}$, Arnis Budi SUSANTO², Yulita indah PERMATASARI ${ }^{3}$ \\ 1,2,3 Faculty of Economics and Business, Universitas Jember, Indonesia \\ Email: purnamie@unej.ac.id ${ }^{1}$, arnisbudisusanto@gmail.com² \\ * Corresponding Author
}

\author{
Received: 01.08.2021
}

Accepted: 23.09.2021 Published: 16.10.2021

DOI: $\underline{\text { 10.47750/QAS/22.184.21 }}$

\begin{abstract}
This study aims to determine and examine the significant influence of internal communication, work discipline, and employee loyalty on the performance of PT. Perkebunan Nusantara XII (Persero). This research is categorized as explanatory research. The population of this research is all field employees as many as 305 employees and the sample taken is 200 employees. The data analysis method used in this research is the Structural Equation model using PLS. The results of this study indicate that internal communication has a significant effect on the performance of the field employees of PT. Perkebunan Nusantara XII (Persero), work discipline has a significant effect on the performance of the field employees of PT. Perkebunan Nusantara XII (Persero), and employee loyalty have a significant effect on the performance of the field employees of PT. Perkebunan Nusantara XII (Persero).
\end{abstract}

Keywords: Internal Communication, Work Discipline, Employee Loyality, Employee Performance

\section{Introduction}

Every company certainly has goals to achieve. One of the important assets that can support the achievement of company goals, namely human resources. Human resources determine the success of strategies, policies, and steps in the activities of companies and organizations. Companies must be able to manage their resources through improving employee performance. According to Mangkunegara (2011: 67), performance is the quality and quantity of work achieved by an employee in carrying out his duties in accordance with the responsibilities assigned to him. Employee performance determines the progress of the company. If the employee's performance is good, the greater the chances of the company's progress and success rate, and vice versa.

PT. Perkebunan Nusantara XII (Persero) is a fairly large producer of rubber and sugarcane. PT. Perkebunan Nusantara XII (Persero) processes latex / rubber latex into Ribbed Smoked Sheets (RSS) to meet local and export demands. In addition, PT. Perkebunan Nusantara XII (Persero) is one of the PT. Perkebunan Nusantara XII (Persero) which is hoped to be able to achieve self-sufficiency in sugar. PT. Perkebunan Nusantara XII (Persero) certainly expects quality performance in order to be able to achieve production targets and compete with PT Perkebunan Nusantara XII (Persero).

The results of interviews with several field employees (including personnel), the problems that occurred at PT. Perkebunan Nusantara XII (Persero) deals with internal communication, work discipline, and employee loyalty. Internal communication to the field employees of PT. Perkebunan Nusantara XII (Persero) is still not optimal. It can be seen that when superiors give orders to employees in an urgent situation through communication tools, there are still some employees who do not clearly understand the instructions ordered by their superiors so that there is a misunderstanding of the information conveyed. Another problem related to internal communication is the difficulty in submitting work-related complaints. Bosses give employees the freedom to present arguments. However, most employees feel afraid, awkward, and lack the ability to communicate so they tend to hide and bury all the complaints they want to convey themselves. On the other hand, employees feel that there is a lack of activities that can establish communication and closeness in the company so that most employees speak as necessary to other employees.

Work discipline on the field employees of PT. Perkebunan Nusantara XII (Persero) is still not optimal. The disciplinary violation was in the form of several employees who often did not appear on time according to the working hours. Some employees still arrive late beyond the predetermined working hours. Some employees arrive late because of personal interests, wake up late, and are far from home from work. In addition, the road conditions that were damaged and a little muddy during the rainy season also caused some employees to arrive late.

Another problem that occurs in the field employees of PT. Perkebunan Nusantara XII (Persero), namely the issue of employee loyalty. In the past, the field employees of PT. Perkebunan Nusantara XII (Persero) works wholeheartedly without paying attention to rewards to keep trying to maintain the company's existence. However, at this time the field employees of PT. Perkebunan Nusantara XII (Persero) is not as loyal as before. Employees do not really care about the existence and progress of the company. Employees only think that the most important thing is to come to work and get a salary or wage so that employee loyalty is low. In addition, there is a lack of pride among employees for the company. This can be seen from employees sometimes telling related management 
problems and internal company problems outside the company.

The decrease in employee loyalty is due to several things including the employee's annual assessment that is considered not optimal by the boss even though the employee has done the job as much as possible, overtime wages that are not in line with employee expectations, and the employee's working period is approaching retirement.

This study aims to determine and examine the effect of internal communication, work discipline, and employee loyalty on the performance of PT. Perkebunan Nusantara XII (Persero).

\section{Literature Review}

Romli (2014: 6) explains that internal communication is the process of delivering messages or information that occurs between members of an organization for the benefit of the organization. According to Robbins (2013) Communication helps develop motivation by explaining to employees what to do, how they work well and what to do to improve performance if it is below standard. According to Argenti (2013) states that an organization needs internal communication between superiors and subordinates to maintain relationships so that they are open to each other in terms of work. Therefore, all work activities cannot be separated from communication. Communication that occurs in the company can help to explain the company's strategic goals. Previous research conducted by Rahmad Restu Udayanto, I Wayan Bagia, and Ni Nyoman Yulianthini (2015), Gita Lestari and Kasmirudin (2017), and Stefanny Angelica Pangendaheng (2018) proved that internal communication has a positive and significant effect on employee performance. Thus, the first hypothesis is that internal communication has a significant effect on the performance of the field employees of PT. Perkebunan Nusantara XII (Persero).

According to Singodimedjo in Sutrisno (2016: 86), discipline is the attitude of a person's willingness and willingness to obey and obey the regulatory norms that apply around them. Good employee discipline will accelerate the company's goals, while slumping discipline will become a barrier and slow down the achievement of company goals. Lijan Poltak (2016: 332) Discipline is the most important operational function of human resource management because the better employee discipline, the higher work performance they can achieve. Afandi (2018: 12) argues that discipline is needed by an organization to maintain its existence, because with high discipline, employees will obey any existing regulations and carry out work according to a predetermined plan. Previous research conducted by Fikratunil Khasifah and Rini Nugraheni (2016), Jeli Nata Liyas and Reza Primadi (2017), Santiago Pereira and Syahnur Said (2019) proved that work discipline has a significant and positive effect on employee performance. Thus, the second hypothesis, namely work discipline has a significant effect on the performance of the field employees of PT. Perkebunan Nusantara XII (Persero).

According to Hasibuan (2014: 95), Loyalty is employee loyalty to work, position and company. This loyalty is reflected by the willingness of employees to maintain and defend the organization both inside and outside of work from undermining irresponsible people. According to Ismail and Razak (2016: 32), employees who have high loyalty to their organization will optimize all their abilities to support the progress of the organization. Ardana, et al (2012: 137) said that if employees have high loyalty, the employee's performance can be guaranteed over time. Previous research conducted by Yuli Astuti (2016), Lydia Gomes I and Eddy Madiono Sutanto (2017) Arisona Chony Ronaldy, Irsan Tricahyadinata, and Siti Maria (2019) proved that employee loyalty has a significant and positive effect on employee performance. Thus, the third hypothesis, namely employee loyalty has a significant effect on the performance of the field employees of PT. Perkebunan Nusantara XII (Persero).

\section{Research Model}

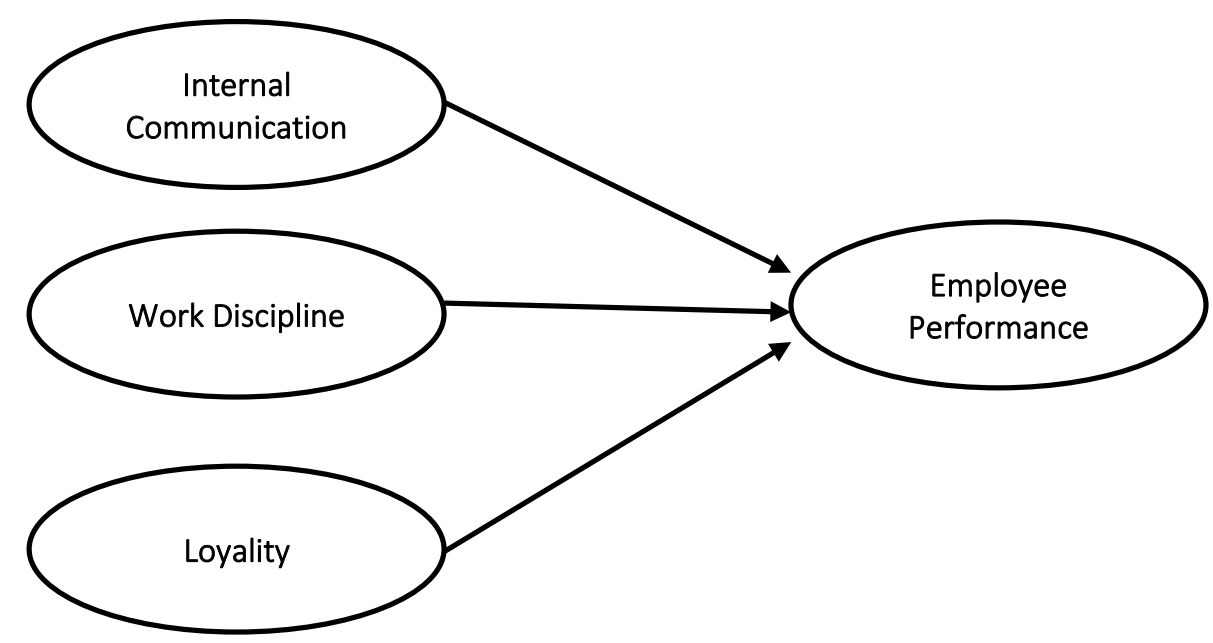

Figure 1: Research Model

\section{Method}

This research is included in the category of explanatory research because it intends to explain the relationship between internal communication, work discipline, and employee loyalty to the performance of the field employees of PT. Perkebunan
Nusantara XII (Persero). The type of data used in this research is quantitative qualitative data. Because the data is processed and analyzed using statistical calculation techniques with a Likert scale. Sources of data obtained from primary data sources and secondary data sources. Methods of data collection are carried out through interviews, questionnaires, 
and literature study. The population in this study were all employees of PT. Perkebunan Nusantara XII (Persero) totaling 305 employees and a sample of 200 employees. The sampling technique in this study used probability sampling with the type of simple random sampling. The data analysis method used in this study is the Structural Equation Model using Partial Least Square. The measurement scale in this study uses a Likert scale, the Likert scale is used to measure the attitudes, opinions, perceptions of a person or group of people about social events or symptoms (Riduwan and Kuncoro, 2017: 20).

\section{Result \\ Convergent Validity Test}

To meet the convergent validity test, the Average Variance Extracted (AVE) value must be greater than 0.5. The Average Variance Extracted (AVE) value is presented in Table 1 which is obtained from the PLS Algorithm calculation.

\begin{tabular}{|l|l|l|}
\hline Variable & AVE & Description. \\
\hline Internal Communication & 0,582 & Valid \\
\hline Work Discipline & 0,689 & Valid \\
\hline Loyality & 0,711 & Valid \\
\hline Performance & 0,727 & Valid \\
\hline
\end{tabular}

Table 1: AVE Value

Source: processed data, 2020

Based on Table 1. it can be concluded that all construct values are feasible or valid for use.

\section{Reliability Test}

The results of reliability testing are presented in Table 2. showing the value of Internal communication, Work Discipline, Loyality, employee performance, indicating that the indicators used in this study are reliable.

\begin{tabular}{|l|l|l|l|}
\hline Variable & $\begin{array}{l}\text { Composite } \\
\text { Reliability }\end{array}$ & $\begin{array}{l}\text { Cronbach's } \\
\text { Alpha }\end{array}$ & Description \\
\hline $\begin{array}{l}\text { Internal } \\
\text { Communication }\end{array}$ & 0,905 & 0,884 & Reliable \\
\hline Work Discipline & 0,869 & 0,772 & Reliable \\
\hline Loyality & 0,856 & 0,788 & Reliable \\
\hline Performance & 0,908 & 0,864 & Reliable \\
\hline
\end{tabular}

Table 2: Composite Reliability dan Cronbach's Alpha

Source: processed data, 2020

\section{Hypothesis testing}

Based on the results of hypothesis testing, a summary of the results of hypothesis testing is produced. The significance of the structural model was assessed by comparing the t-statistic with the $\mathrm{t}$-table. The $\mathrm{t}$-table is sought at $\alpha=5 \%$ with degrees of freedom (df) $=n k$, where $n$ is the number of samples, and $k$ is the number of variables used in the study, so that the degrees of freedom $(\mathrm{df})=46-3=43$. The results of $\mathrm{t}-\mathrm{The}$ research table is 2.01. For hypothesis testing, in this study all research hypotheses were accepted.

\section{Discussion}

The Influence of Internal Communication on Employee Performance

Based on the results of multiple analyzes, it shows that the more positive the employees' perceptions of the facts of internal communication that occur, the better the performance produced by the field employees of PT. Perkebunan Nusantara XII (Persero).

The characteristics of respondents based on gender also influence the results of this study, where the majority of the employees are male. The majority of male employees perceive internal communication well. Male employees tend to communicate directly when problems occur, such as work complaints, so they come straight to their superiors. Because male employees are always eager to solve problems that occur, they are quick to act when there is a problem. This is intended so that the problems that occur do not interfere with employees when carrying out work so that they can focus more on work. In addition, male employees are able to actually provide support to other employees in the workplace even with people they don't like. Male employees are able to differentiate between work and personal feelings. Therefore, men are able to do their jobs well so that the resulting performance is in line with company expectations.

The results of this study are in line with research previously conducted by Gita Lestari and Kasmirudin (2017) which analyzed the effect of internal communication on the performance of employees of PT. Riau Media Television (Rtv) Pekanbaru. His research uses multiple linear regression analysis and the results obtained in the form of internal communication have a significant effect on the performance of the employees of PT. Riau Media Television (Rtv) Pekanbaru. Internal communication that occurs at PT. Perkebunan Nusantara XII (Persero) was perceived well. It can be seen from communication activities towards the top where employees can 
submit job complaints to superiors and are responded well so that they get solutions for the common good. This is able to make employees work comfortably in carrying out their work so that they are passionate about work. In addition, downward communication activities where the boss is able to give clear orders related to work. Not only that, the boss also gives a warning if something goes wrong in doing the job. It is intended that employees are able to understand how to do a good job so that the work carried out by employees is in accordance with the standards set by the company. In horizontal communication, employees are able to provide support to fellow employees and foster relationships through joint activities so as to minimize conflicts within PT. Perkebunan Nusantara XII Persero) and able to strengthen solidarity between employees. Therefore, internal communication can improve employee performance. So, it can be concluded that internal communication has a significant effect on the performance of field employees of PT. Perkebunan Nusantara XII (Persero).

\section{The Effect of Work Discipline on Employee Performance}

Based on the results of the analysis, it shows that Work Discipline (X2) has a significant effect on Employee Performance $(Y)$. This shows that the better the work discipline of the field employees of PT. Perkebunan Nusantara XII (Persero), the employee's performance will increase.

The characteristics of the respondents based on age also influenced the results of this study. The majority of employees who work at PT. Perkebunan Nusantara XII Kebun Mumbul (Persero) is 31-40 years old. Employees who are 31-40 years old are classified as adults so that employees have ambition and are organized in carrying out their work so that at the age of 31 40 they tend to have good work discipline. In addition, 31-40 years of age are included in the productive age where at this age employees have a stable body condition so that they can do work energetically and are able to comply with applicable regulations. At the age of 31-40 years of employees have had work experience that is able to support the implementation of work properly so that they are more careful and careful in their work to avoid mistakes in carrying out their work. Of course, with the employee's ability to do the job properly, it can produce the performance to be achieved.

The results of this study are in line with research previously conducted by Jeli Nata Liyas and Reza Primadi (2017) which analyzed the effect of work discipline on employee performance of the Rokan Hulu People's Credit Bank. The research used simple linear regression analysis and the results showed that work discipline had a significant effect on the employee performance of the Rokan Hulu People's Credit Bank. Work discipline on the field employees of PT. Perkebunan Nusantara XII Kebun Mumbul (Persero) was perceived well. Employees are able to attend on time according to predetermined working hours so that work is completed in a faster time. That way, employees manage time properly so that employees avoid wasting energy and time in carrying out work. Employees also perform work in accordance with Standard Operating Procedures (SOPs) that have been determined by the company and get maximum work results. Because employees do not feel doubt about the job given so that employees are able to work independently. In addition, employees have a careful attitude in carrying out the work that has been determined by the company. This careful attitude makes employees avoid mistakes in their work and employees can achieve the targets set by the company. Not only that, employees are also polite when they are at work. This has led to the growth of mutual respect, which encourages employees to be active in their work. That way, employees are able to carry out work within a predetermined time. Of course, good work discipline ensures that the rules are maintained and encourages enthusiasm for work so that the field employees at PT. Perkebunan Nusantara (Persero) is able to produce the maximum possible performance. So, it can be concluded that work discipline has a significant effect on the performance of field employees of PT. Perkebunan Nusantara XII (Persero).

\section{The Effect of Employee Loyalty on Employee Performance}

Based on the results of the analysis shows that the higher the loyalty of the field employees of PT. Perkebunan Nusantara XII (Persero), the employee's performance will increase.

Characteristics of respondents based on length of work also influenced the results of this study, where the majority of employees worked for more than 5 years. Employees who have worked for more than 5 years prove that the majority of PT. Perkebunan Nusantara XII has high loyalty to the company. Because they feel fit and comfortable working at PT. Perkebunan Nusantara XII so that they have survived to this day. Employees are able to commit to the company even though there are job opportunities from other companies for them. Employees tend to carry out work with a sense of pleasure so that they are able to faithfully work longer in the company and are able to do the job not only well but as well as possible. The length of time employees work can help employees to have more knowledge in the work given so that it helps employees to be able to produce optimal performance.

The results of this study are in line with research previously conducted by Yuli Astuti (2016). His research uses multiple linear regression analysis and the results are that loyalty has a significant effect on the performance of the employees of $\mathrm{PT} . \mathrm{Zi}$ Vision, Pangkalan Kerinci Branch, Pelalawan Regency. Loyalty of the field employees of PT. Perkebunan Nusantara XII (Persero) was perceived well. Employees uphold the company's vision and mission in carrying out their work so that they can be more motivated to try to give the best results according to the expectations of PT. Perkebunan Nusantara XII Kebun Mumbul (Persero). Therefore, employees are able to do work according to the target and of good quality. Employees are also willing to cooperate with other employees so that the work done can be done faster. That way, employees are able to maximize the use of organizational resources according to the needs of PT. Perkebunan Nusantara XII (Persero). Not only that, employees also do their job happily, are able to last a long time in the workplace and feel proud of PT. Perkebunan Nusantara XII (Persero). Therefore, they are very responsible for their work and are able to work optimally for the continuity of PT. Perkebunan Nusantara XII (Persero). So, it can be concluded that employee loyalty has a significant effect on the performance of the field employees of PT. Perkebunan Nusantara XII (Persero)

\section{Conclusion}

This study aims to determine and examine the significant influence of internal communication, work discipline, and employee loyalty on the performance of PT. Perkebunan Nusantara XII (Persero). The research findings indicate that internal communication has a significant effect on the performance of field employees at PT. Perkebunan Nusantara XII (Persero), work discipline has a significant effect on the performance of field employees at PT. Perkebunan Nusantara XII I (Persero), and employee loyalty have a significant effect on the performance of field employees at PT. Perkebunan Nusantara XII (Persero).

This study has limitations, namely the Covid-19 pandemic conditions are an obstacle for researchers in the data collection 


\section{GENERAL MANAGEMENT}

process. In addition, the process of collecting data on respondents' answers takes a long time because questionnaires are still being distributed manually. Therefore, suggestions for further researchers should be that questionnaires are distributed to respondents to take advantage of technological advances through Google Forms to be more efficient in terms of time and paperless. In addition, further researchers are expected to add other variables that can affect employee performance and increase the number of research samples so that the data obtained is more accurate.

\section{Reference}

[1] Afandi, P. (2018). Human Resource Management (Theory, Concepts and Indicators). Riau: Zanafa Publishing

[2] Ardana, I Komang, et al. 2012. Human Resource Management. Yogyakarta: Graha Science.

[3] Argenti PA. 2013. Corporate Communication. Singapore: McGraw-Hill International Edition.

[4] Astuti, Yuli. 2016. The Effect of Supervision and Loyalty on Employee Performance in the Cable TV Industry (Study at Pt. Z Vision, Pangkalan Kerinci Branch, Pelalawan Regency). JOM FISIP, 3 (2).

[5] Hasibuan, Malayu SP. 2014. Human Resource Management. Jakarta: Earth Literacy.

[6] I, Lydia Gomes and Eddy Madiono Sutanto. The Influence of Work Motivation and Employee Loyalty on Employee Performance in CV Hartono Flash Surabaya. Agora, 5 (2).

[7] Ismail, A., \& Razak, M. R. (2016). The Effect Of Job Satisfaction On Organizational Commitment. Management \& Marketing, 14 (1), 25-40.

[8] Khasifah, Fikratunil and Rini Nugraheni. 2016. The Effect of Work Discipline, Workload and Work Environment on Employee Performance (Study at the Pemali Juana River Basin). Diponegoro Journal of Management, 5 (1), 334-340.
[9] Lestari, G. and Kasmirudin. 2017. The Influence of Internal Communication and Work Motivation on Employee Performance in Media Industry PT. Riau Media Television (Rtv). Pekanbaru. JOM FISIP, 4 (2).

[10] Liyas, J.N. and Reza Primadi. 2017. The Effect of Work Discipline on Employee Performance at Bank Perkreditan Rakyat. Al-Masraf: Journal of Financial Institutions and Banking, $2(1), 17-26$.

[11] Mangkunegara, A. A, Anwar Prabu. 2011. Tenth Printing Human Resource Management. Bandung: Youth Rosdakarya.

[12] Pangendaheng, Stefanny Angelica. 2018. The Influence of Organizational Internal Communication, and Organizational Commitment on the Performance of Bank Maya Employees at the Mapan Indah Ruko Branch. Agora, 6 (1).

[13] Pereira, Santiago and Syahnur Said. 2019. The Influence of Work Discipline, Work Environment, and Work Motivation on Employee Performance. PARADOKS: Journal of Economics, 2 (2), 47-59.

[14] Poltak, Lijan. 2016. Human Resource Management. Jakarta: Earth Literacy.

[15] Romli, Khomisahrial. 2014. Complete Organizational Communication. Jakarta: PT Grasindo.

[16] Ronaldy, Arisona Chony, Irsan Tricahyadinata, and Siti Maria. 2019. The Effect of Employee Loyalty, Emotional Intelligence, and Work Discipline on Employee Performance. Journal of Management, 11 (2), 116-122.

[17] Sutrisno, Edy. 2016. Human Resource Management in the 8th edition. Jakarta: Kencana Prenada Media Group.

[18] Udayanto, Rahmad Restu, I Wayan Bagia, and Ni Nyoman Yulianthini. 2015. The Influence of Internal Communication and Work Discipline on Employee Performance at PT Coca-Cola. Indonesian Journal of Management, 3 (110) 